\title{
FogYATÉKOSSÁGOK HETE A BERKELEY EGYETEMEN
}

\author{
FLAMICH MÁRIA * - HOFFMANN RITA ** \\ *az ELTE PPK Neveléstudományi Doktori Iskola Tanulás-Tanítás Program \\ Fulbright ösztöndíjas hallgatója \\ flamich.maria@chello.hu \\ ** az ELTE PPK Neveléstudományi Doktori Iskola Tanulás-Tanítás Program \\ Fulbright ösztöndíjas hallgatója \\ hoffmann.rita@chello.hu
}

\begin{abstract}
„Gördülj és löj!” (Roll N' Shoot) Ezzel a felhívással és egy kerekesszékes kosárlabda meccsel kezdődött - immár hatodik alkalommal - a Fogyatékosságok Hete (Disability Awareness Week) címü eseménysorozat a Berkeley Egyetemen (University of California, Berkeley) 2012. március 11-én vasárnap a Fogyatékos Hallgatók Egyesülete (Disabled Student's Union) rendezésében. A nevezési díj egy négyfös csapat számára 250 dollár volt, ami az adóból levonható. A befolyt összeget az Öbölkörnyéki Fogyatékosok Szabadidős és Sportprogramjai (Bay Area Outreach and Recreation Program) támogatására fordítják. Az érdeklődők délelőtt 10 órától ülhettek kerekesszékbe, hogy megismerkedjenek a játék sajátosságaival, fortélyaival, izgalmaival és mindenekelőtt örömével. A közös játék garantálta a kihívásokat, a felejthetetlen élményt és a saját tapasztalaton alapuló ismereteket, amelyeken keresztül a játékosok bepillantást nyertek a kerekesszékes sport kulisszatitkaiba.

Érzékenyités! Figyelemfelhívás! Kampány! - gondolhatnánk, ha Berkeleyben nem lenne valamennyi utcasarok a látás- és mozgássérültek számára egyaránt jól látható, megfelelően lekerekített és egyben érezhető taktilis jelzéssel ellátott; ha nem tudnánk, hogy minden középület megközelíthetö és bejárható kerekes székkel; ha nem látnánk a bankautomaták braille feliratait, ha nem lenne minden jegyváltóés bankautomatán fülhallgatónak kialakított hely, ami azt jelenti, hogy képernyőolvasó szoftverrel is használható; ha nem lenne természetes, hogy a metró, azaz itt BART (Bay Area Rapid Transit), mélyállomásába lifttel egyszerü lejutni, és ha nem lenne legalább annyira könnyü a beszállás a metrókocsikba.

Berkeley, a fogyatékosságjogi mozgalmak bölcsője, számos szempontból akadálymentes város. Itt a mindennapokban is láthatóan és tevékenyen jelen van a fogyatékossággal élő személy. Mindenki találkozhat vele az utcákon járókelőként, a bankokban alkalmazottként, a vonatokon utasként és a kampuszban egyetemi hallgatóként, oktatóként egyaránt. Felmerül a kérdés: Miért van szükség Berkeleyben, a világ egyik legakadálymentesebb és legliberálisabb városában a Fogyatékosságok Hetére? Az egyik lehetséges magyarázat az, hogy az emberek az állandó és
\end{abstract}


aktív jelenlét ellenére, még mindig keveset tudnak a fogyatékossággal élő személyekről. Meglepő, de számos érintett úgy véli, ez még itt is igaz. A másik megközelítés szerint pedig a fogyatékossággal élő személyeknek - mint bárki másnak szükségük van olyan fórumokra, ahol elmondhatják, mit gondolnak a párkapcsolatokról, a szexről, a fogyatékosságról, mint társadalmi konstruktumról, vagy a fogyatékosság elfogadásáról. Ezt a kétféle megközelítést ötvözte és tükrözte a Fogyatékosságok Hetének valamennyi eseménye, ahol minden érdeklődő tabuk és félelem nélkül kérdezhetett, beszélgethetett a meghívott előadókkal, akik többségében az egyetem fogyatékossággal élő hallgatói és professzorai.

Magától értetődően a rendezvénysorozat minden tekintetben összhangban volt az ADA (The Americans with Disabilities Act) előírásaival, így az akadálymentesség a megközelíthetőségen túl a jelnyelvi tolmácsolást és a valósidejü feliratozást is jelentette. A rendezők a programok összeállítása során nagy hangsúlyt fektettek arra, hogy bemutassák a fogyatékossággal élő személyek sokszínüségét.

A vasárnapi kosárlabda meccset hétfön egy teljesen más profilú, de nem kevésbé érdekes esemény, „A fogyatékosok és a szex” (Are Cripples Screwed?) címü fórum követte. A beszélgetés kiindulópontja a fogyatékossággal élő személyek szexualitásának filmbeli ábrázolása volt. A fórum rávilágított arra a talán kevésbé ismert tényre, hogy a filmvilág általában teljesen aszexuális képet fest a fogyatékossággal élő személyekről, amennyiben mégsem, úgy kiszolgáltatott, szánalmas szerepbe kényszeríti őket. A fórum résztvevői egybehangzóan kijelentették, „,a fogyatékosság nem korlátozza vagy akadályozza tartalmas párkapcsolatok kialakulását, illetve a szexualitást.”.

A „Fogyatékosság filozófiája” (The Philosophy of Disability) címü beszélgetés újabb oldalról közelített a fogyatékosság, valamint a fogyatékossággal élő személyek felé. Arra a kérdésre keresett választ, milyen szerepet játszik a társadalom a fogyatékosság társadalmi konstrukciójában. A beszélgetésből egy új fogalom, a mellőzés episztemológiája (the epistemology of ignorance) értelmezése bontakozott ki. Valamennyi megszólaló nagy hangsúlyt fektetett a fogyatékossággal kapcsolatos igazságok feltárására, és a jelenleg még uralkodó, gyakran kedvezőtlen szemléletmegváltoztatását célzó törekvések elemzésére, értékelésére. A fórumon meghívott előadóként fogyatékossággal élő társadalomtudós, politológus és író, valamint a Bölcsészkar fogyatékossági mozgalmak mellett elkötelezett, nem fogyatékossággal élő dékánhelyettese vett részt.

A negyedik esemény a legendás AXIS Dance Company táncegyüttes előadása volt. Az együttes 1987 óta müködik, profilja elsősorban a modern táncmüvészet, tagjai a hagyományos értelemben ismert táncosok mellett, kerekesszékes, valamint müvégtagokkal rendelkező müvészek. Az együttes müfajt teremtett az által, hogy a világon elsőként ismerte fel a müvészet kifejező erejét a fizikailag más képességekkel rendelkező emberekben. A ,,So You Think You Can Dance” címü, Amerikában népszerü tévéprogramból is jól ismert, több alkalommal Isadora Duncan Díjjal 
kitüntetett együttes exkluzív előadásával hívta fel a figyelmet a fogyatékossággal élő személyek - itt már ismert és elismert - értékeire.

„Fogyatékosság - Miért törödnénk vele?” (,Disability, Why Should We Care?”) Az ötödik esemény címe jóllehet figyelemfelkeltő, mégsem sejttette a beszélgetés valódi tartalmát. A zárófórum ugyanis visszatekintett a múltra, ismertette a jelent és lassan körvonalazta a jövőt, ahol nem tabu, nem szégyen a fogyatékosság, beszélni kell róla, meg kell ismerni. Ezt a megközelítést támasztotta alá valamennyi résztvevő, akik közül hadd említsünk meg egy legendás személyiséget, Zona Robertset, a fogyatékosságjogi mozgalmak elindítója $E d$ Roberts édesanyját. A kilencvenkét éves hölgy páratlan tisztánlátással beszélt szülői szerepről, érdekérvényesítésről, a mindennapok gondjairól, méltóságról és a fogyatékosság elfogadásáról.

A március 11-e és 16-a között rendezett eseménysorozat közeli, ám mégis tárgyilagos képet mutatott a fogyatékos személyek sokszínüségéröl. Személyes történetekből tudhattuk meg, hogyan fogadja el egy szülö gyermeke fogyatékosságát, egy csapatban vagy ellenfélként üdvözölhettük a fogyatékos sportolót, együtt gondolkodhattunk a fogyatékos tudóssal, politológussal, kérdezhettük a vak írót világlátásáról, találkozhattunk kerekesszékes müvészekkel, - de mindenekelőtt - megismerhettük a fogyatékos embert, aki a hétköznapok, a sport, a tudomány vagy a müvészetek eszközeivel legjobb tudása és képessége szerint arra törekszik, hogy eloszlassa a fogyatékossággal élő embert övező félreértéseket, sztereotípiákat és elöítéleteket. 